\title{
Aplikasi Titip Online Produk UMKM Berbasis Android
}

\author{
Febrian Hidayat ${ }^{1^{*}}$, Muhamad Sadali ${ }^{2}$, Aris Sudianto ${ }^{3}$ \\ 1,2,3Program Studi Teknik Informatika, Fakultas Teknik Universitas Hamzanwadi \\ *febrianhidayat714@gmail.com
}

\begin{abstract}
Abstrak
UMKM memiliki peranan besar dalam meningkatkan pertumbuhan perekonomian di daerah dengan meningkatknya jumlah UMKM di suatu daerah maka akan menunjukan aktivitas transaksi jual beli akan semakin meningkat, tak terkecuali di Kecamatan Selong Kabupaten Lombok Timur. Dengan hadirnya UMKM baru mampu menjadi solusi untuk menekan angka pengangguran di Kabupaten Lombok Timur, namun di samping itu mampu untuk menekan angka pengangguran namun sangat perlu untuk di lakukan bagaimana cara agar produk-produk para pelaku UMKM dapat di akses secara lebih luas, karena mengingat masyarakat pada saat ini sangat aktif dalam menggunakan smartphone. Tujuan dari penelitian ini adalah membuat aplikasi yang nantinya mampu untuk menampung segala bentuk produk para pelaku UMKM di Kecamatan Selong yang tentunya dengan aplikasi ini akan mampu untuk menguntungka kedua belah pihak, yaitu masyarakat sebagai pelanggan dapat mencari produkproduk UMKM favoritnya melalui smartphone, sedangkan untuk para pelaku UMKM dapat mempromosikan produknya secara lebih luas sehingga dapat meningkatkan jumlah penjualan dari pada sebelumnya.
\end{abstract}

Kata kunci : UMKM, Aplikasi Android, Firebase, Java, Map Find Location

\begin{abstract}
UMKM have a big role in increasing economic growth in the region by increasing the number of UMKM in an area, it will show that buying and selling transaction activities will increase, not least in Selong District, East Lombok Regency. With the presence of the new UMKM, it is able to be a solution to reduce unemployment in East Lombok Regency, but in addition to being able to reduce the unemployment rate, it is very necessary to do how so that the products of UMKM actors can be accessed more widely, because considering the community at this time very active in using smartphones. The purpose of this research is to create an application that will be able to accommodate all forms of products of UMKM actors in Selong District which of course with this application will be able to benefit both parties, namely the community as customers can search for their favorite UMKM products via smartphones, while for UMKM actors can promote their products more broadly so that they can increase the number of sales than before.
\end{abstract}

Keywords : UMKM, Aplikasi Android, Firebase, Java, Map Find Location

\section{Pendahuluan}

UMKM dikenal sebagai akronim dari Usaha Mikro

Kecil Menengah. Peran UMKM dalam mendorong pergerakan dan pembangunan di daerah sangatlah penting dan mampu untuk menekan jumlah pengangguran. Namun meningkatnya jumlah pelaku UMKM tidak dibarengi dengan pemahaman terkait dengan peran teknologi dalam proses pemasaran produk, tak terkecuali di sekitar Kelurahan Selong, Kecamatan Selong, 
Kabupaten Lombok Timur.

Penelitian ini mengambil objek dari para pelaku UMKM yang ada di Kelurahan Selong, Kecamatan Selong, Kabupaten Lombok Timur. Para pelaku UMKM memiliki berbagai macam produk mulai dari Kuliner, Kerajinan, Pakaian, dan lain-lain.

Data yang terdapat di Dinas Koperasi Kabupaten Lombok Timur pada tahun 2020 jumlah UMKM secara keseluruhan 2936 dengan rincian 2138 tergolong usaha mikro, 570 usaha kecil, dan 48 usaha menengah. Di Kecamatan Selong pada tahun 2020 terdapat 450 peningkatan yang cukup tinggi dari tahun 2019 dengan total 289 UMKM.

Hadirnya pandemi Covid-19 memberikan dampak yang signifikan terhadap para pelaku UMKM ditambah lagi dengan diberlakukannya aturan yang merubah aktivitas sosial kita yang melarang berkerumun dan keluar rumah. Penyebaran Covid-19 telah menghambat kegiatan perekonomian dan dampaknya terhadap tingkat kesejahteraan sosial makin dirasakan masyarakat. UMKM yang menjadi salah satu penopang pertumbuhan ekonomi daerah mengalami kerugian yang cukup besar diakibatkan dengan pandemic Covid-19.

Kurangnya pemahaman terkait dengan teknologi mengakibatkan para pelaku UMKM yang ada di Kecamatan Selong sulit untuk berkembang ditambah lagi dengan hadirnya platform jual beli online. Diharapkan dengan hadirnya aplikasi Titip
Online yang mengedapankan User friendly, sehingga dapat digunakan dan dipahami dengan mudah oleh para pelaku UMKM serta dapat memasarkan produk-produknya secara lebih luas.

Aplikasi Titip Online untuk para pelaku UMKM dapat juga sekaligus mengedukasi para pelaku UMKM dengan cara memberikan penjelasan terkait fitur apa saja yang terdapat didalam aplikasi sehingga para pelaku UMKM nantinya dapat mengakses produknya secara langsung dari smartphone dan para pelaku UMKM dapat menambahkan produk-produk yang dimiliki secara mandiri.

Penelitian ini akan membuat dan menghasilkan sebuah aplikasi yang nantinya akan menguntungkan kedua belah pihak, yaitu untuk konsumen dapat menggunakan aplikasi ini untuk mendapatkan olahan makanan ringan secara lebih mudah hanya tinggal mengaksesnya dari aplikasi secara online, sedangkan untuk para pelaku UMKM tentunya produk-produknya akan diakses secara lebih luas dan tentunya dapat menghasilkan keuntungan yang lebih tinggi dari pada sebelumnya sehingga aplikasi ini sebagai jembatan penghubung antara konsumen dan para pelaku UMKM untuk melakukan proses jual beli.

\section{Tinjauan Pustaka}

\subsection{Penelitian Terkait}

Beberapa penelitian terkait dengan Aplikasi titip 
online produk umkm berbasis android diantaranya adalah sebagai berikut :

Penelititan yang dilakukan oleh Sonita, Anisya, Fardianitama dan Rizki Fitrah pada jurnal yang diberi judul "Aplikasi E-Order Menggunakan Firebase Dan Algoritme Knuth" didapat kesimpulan Aplikasi e-Order pada rumah makan semalam suntuk berbasis android menggunakan firebase dan algoritme Knuth Morris Pratt berhasil dibuat menggunakan software android studio, Aplikasi yang dibuat menghadirkan Pemberitahuan secara otomatis sehingga dapat mempermudah pengguna atau user untuk mendapatkan informasi seputar tentang makanan yang masih tersedia. Aplikasi e-Order pada rumah makan semalam suntuk ini dapat menjadi media atau alternatif baru bagi pihak rumah makan dalam memberikan layanan terhadap pelanggan rumah makan semalam suntuk ketika melakukan pemesanan.[1]

Selanjutnya adalah penelitian yang dilakukan oleh Aris Sudianto dan Muhamad Sadali pada jurnal yang diberi judul "Penerapan Aplikasi Berbasis Android Untuk Ternak Ayam Petelur Sebagai Wadah Untuk Menghubungkan Pemilik Modal Dengan Calon Peternak" didapat kesimpulan Peternak ayam petelur memiliki peluang yang besar karena kebutuhan akan telur ayam yang besar dilombok, akan tetapi pemanfaatan teknologi yang saat ini

sanagat pesat belum digunakan secara maksimal untuk memudahkan dalam akses modal kepada peternak maupun pemodal yang ingin bekerjasama dengan peternak dengan cara memberikan modal.[2]

Selanjutnya adalah penelitian yang dilakukan oleh Frediyatma dan Steven Yurie pada jurnal yang diberi judul "Aplikasi Pemasanan Berbasis Cloud Dengan Platform Android" didapat kesimpulan Aplikasi pemesanan makanan berbasis cloud dapat membaca data dari database MySQL dengan parsing menggunakan JSON. Pelanggan dan pelayan harus terdaftar lebih dahulu untuk dapat mengakses menu pada aplikasi. Aplikasi client ini menyediakan layanan berupa insert, update, delete dan read data yang berkaitan dengan pesanan makanan. Sistem ini merupakan sistem yang berbasis cloud, dimana proses-proses yang terjadi pada client selalu mengakses server (internet), oleh karena itu jika terjadi down pada server atau terjadi gangguan maka proses-proses pada aplikasi client akan terganggu sampai server kembali normal. Sistem ini merupakan sistem yang berbasis cloud mengakibatkan pertumbuhan data yang lebih besar karena menyimpan lebih dari satu atau beberapa data restoran serta memuat data semua pelanggan dari seluruh restoran yang terdaftar.[3][4]

Selanjutnya adalah penelitian yangt dilakukan oleh M.Wasil, L.Muhammad Samsu, dan Y. Kuspandi Putra pada jurnal yang diberi judul 
"Sistem Informasi Geografis Untuk Pemetaan Homestay di Lombok Timur Berbasis Android" didapat kesimpulan Berdasarkan analisa dan implementasi yang telah dilakukan, dapat disimpulkan bahwa Sistem Informasi Geografis untuk Pemetaan Homestay di Lombok Timur Berbasis Android dapat membantu wisatawan untuk menemukan homestay di lombok timur, juga mengenai harga, fasilitas dan nomor kontak dari homesty yang akan di kunjungi. Sistem ini dapat dikembangkan dan disempurnakan menjadi lebih baik lagi dan belum ada fasilitas admin yang mengelola data homesty. [5][6]

\subsection{Landsan Teori}

\section{Usaha Mikro}

Usaha mikro kecil menengah atau UMKM adalah istilah umum dalam khazanah ekonomi yang merujuk kepada usaha ekonomi produktif yang dimiliki perorangan maupun badan usaha sesuai dengan kriteria yang ditetapkan oleh Undangundang No. 20 tahun 2008. Yang termasuk kriteria usaha mikro adalah usaha yang memiliki kekayaan bersih mencapai Rp. 50.000.00,- tidak termasuk bangunan dan tanh tempat usaha.[7]

\section{UMKM}

USAHA MIKRO KECIL DAN MENENGAH

Gambar 1. UMKM

\section{Android}

Android adalah sebuah sistem operasi untuk ponsel yang berbasis Linux. Android SDK (Software Development Kit)

menyediakan tools dan API (Application Programming Interface) yang diperlukan bagi para pengembang untuk membuat dan mengembangkan aplikasi yang digunakan pada ponsel bersistem operasi Android dengan menggunakan bahasa pemrograman Java.[8][9] Pada tahun 2005 Google mengakuisisi Android Inc yang pada saat itu dimotori oleh Andy Rubin, Rich Miner, Nick Sears, dan Chris White. Yang kemudian pada tahun itu juga memulai membangun platform Android secara intensif. Kemudian pada tanggal 12 November 2007 Google bersama Open Handset Alliance (OHA) yaitu konsorsium perangkat mobile terbuka, merilis Google Android SDK. Dan sambutannya sangat luar biasa, hampir semua media berita tentang IT dan Programming memberitakan tentang dirilisnya Android SDK (Software Development Kit). Google bersama dengan OHA merilis paket software SDK yang lengkap untuk mengembangkan aplikasi pada perangkat mobile yaitu sistem operasi, middleware. Programmer dan developer bisa melakukan segalanya, mulai dari membuat aplikasi pengiriman SMS hanya dengan dua baris kode, hingga mengganti event pada home screen perangkat Android. Selain itu, bahkan dengan mudah kita bisa membuat dan 
mengkustomisasi sistem operasinya, atau mengganti semua aplikasi default dari Google.

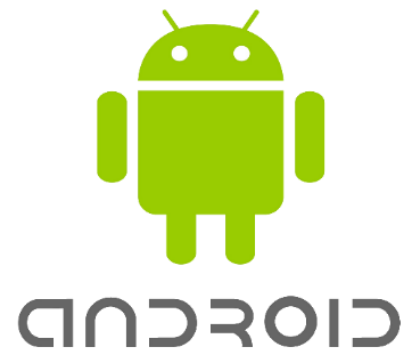

Gambar 2 Android

\section{Firebase}

Firebase adalah penyedia layanan cloud dengan back-end sebagai servis yang berbasis di San Fransisco,California. Firebase membuat sejumlah produk untuk pengembangan aplikasi Mobile ataupun web. Firebase didirikan oleh Andrew Lee dan James Tampilan pada tahun 2011 dan diluncurkan dengan cloud database secara realtime di tahun 2012. Produk utama dari Firebase yakni suatu database yang menyediakan API untuk memungkinkan pengembang menyimpan dan mensinkronisasi data lewat multiple client. Perusahaan ini diakuisisi oleh Google pada Oktober 2014.[10][6]

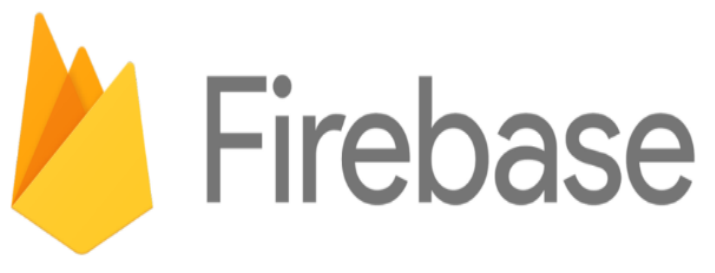

Gambar 3 Firebase

\section{Java}

Java adalah sebuah bahasa pemrograman scripting yang sering digunakan dalam pembuatan aplikasi berbasis handphone dan juga dapat digunakan untuk menyediakan akses objek yang disisipkan di aplikasi lain[11]. Java sebagai salah satu bahasa pemrograman yang sudah berumur dari era 1990-an, kian berkembang dan melebarkan dominasinya di berbagai bidang. Salah satu penggunaan terbesar Java adalah dalam pembuatan aplikasi native untuk Android. Selain itu Java pun menjadi fondasi bagi berbagai bahasa pemrograman seperti Kotlin, Scala, Clojure, Groovy, JRuby, Jython, dan lainnya yang memanfaatkan Java Virtual Machine sebagai rumahnya. Java pun akrab dengan dunia saintifik dan akademik. Di dunia web development sendiri, Java memiliki berbagai web framework unggulan seperti Spring, Play Framework, Spark, Jakarta Struts, dan Java Server Page.[12]

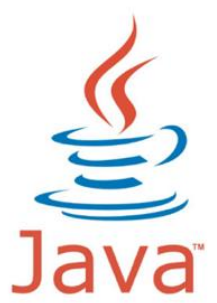

Gambar 4 Bahasa Java

\section{Adobe llustrator}

Adobe ilustrator merupakan salah satu software pengolah gambar berbasis vektor yang di kembangkan dan dipasarkan oleh perusahaan yang bernama Adobe Inc[13]. Vektor merupakan gambar yang terbentuk dari sejumlah garis dan kurva sehingga Ketika diperbesar kualitas gambar tidak akan terlihat pecah. 


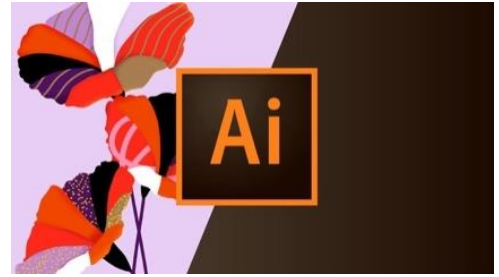

Gambar 5 Adobe lllustrator

\section{Android Studio}

Android Studio adalah IDE (Integrated Development Environment) resmi untuk pengembangan aplikasi Android dan bersifat open source atau gratis. Peluncuran Android Studio ini diumumkan oleh Google pada 16 Mei 2013 pada event Google I/O Conference untuk tahun 2013. Sejak saat itu, Android Studio menggantikan Eclipse sebagai IDE resmi untuk mengembangkan aplikasi Android.[14][15]

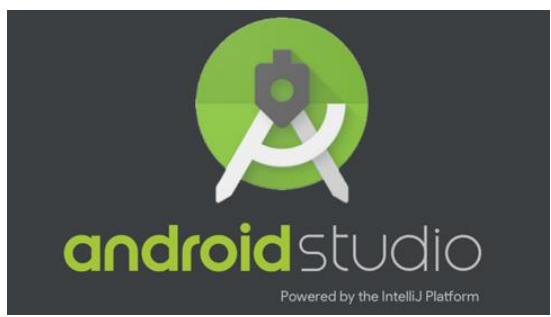

Gambar 6 Android Studio

\section{Metode Penelitian}

\subsection{Metode Pengumpulan Data}

Untuk mendapatkan informasi yang dibutuhkan serta jelas penulisan dilakukan dengan cara :

\section{Observasi}

Observasi merupakan suatu teknik pengumpulan data melalui pengamatan dan pencatatan terhadap suatu peristiwa yang berhubungan dengan object penelitiannya. Pengamatan dilakukan di Rumah Olahan Makanan Ringan Bik Uhin yang berada di Kelurahan Selong, Kecamatan Selong.

\section{Wawancara}

Wawancara merupakan suatu teknik pengumpulan data melalui tatap muka dan tanya jawab langsung dengan sumber data yaitu Rumah Olahan Makanan Ringan Bik Uhin yang berada di Kelurahan Selong, Kecamatan Selong.

3. Studi Pustaka

Suatu metode yang dilakukan dengan membaca dan mempelajari literatur, dokumen - dokumen atau buku - buku yang bisa digunakan sebagai petunjuk dalam melancarkan penelitian.

\subsection{Lokasi Penelitian}

Lokasi penelitian dilakukan di Rumah Olahan Makanan Ringan Bik Uhin yang berada di Kelurahan Selong, Kecamatan Selong, Kabupaten Lombok Timur.

\subsection{Tahapan Penelitian}

Adapun tahapan dari penelitian ini meliputi beberapa tahapan diantaranya :

1. Tahap pengumpulan data dari salah satu rumah olahan makanan ringan di Kelurahan Selong, Kecamatan Selong yang dijadikan sebagai objek penelitian

2. Tahap Analisis

Tahap Analisis ingin merancang dan mengembangkan aplikasi mobile berbasis android yang bernama Titip Online Produk UMKM untuk yang membantu memasarkan 
dan mempromosikan produk UMKM secara lebih luas, sehingga konsumen dapat dengan mudah mengakses produk UMKM melalui smartphone. Aplikasi ini akan dibagi menjadi dua bagian yaitu aplikasi untuk konsumen dan penyedia jasa, di mana sistem kerja pada aplikasi ini adalah konsumen dapat mencari berbagai macam produk UMKM. Lalu konsumen memilih produk yang ingin dipesan dan menentukan jumlah pesanan, selanjutnya menambah pesanan ke dalam daftar keranjang yang selanjutnya bisa langsung melakukan proses pemesanan dan menunggu konfirmasi dari penyedia jasa.

3. Tahap Desain

System desain dilakukan berdasarkan luaran atau output oriented yang artinya inputan dan proses dilihat dari luaran yang diinginkan, sehingga dapat dilihat kebutuhan minimun dari sebuah aplikasi promosi dan pemasaran produk.

4. Tahap Uji Coba

Hasil dari proses yang telah dilakukan diuji coba untuk melihat apakah system yang dihasilkan dapat sesuai dengan yang diinginkan peneliti.

5. Evaluasi

Setelah dilakukan pengujian dan eksperimen terhadap hasil yang dilakukan, maka bisa dilihat perbedaan dari hasil yang dilakukan sebelumnya, apakah dengan aplikasi mobile ini dapat membantu para pelaku UMKM untuk masarkan dan mempromosikan produk UMKM sehingga dapat meningkatkan jumlah penjualan.

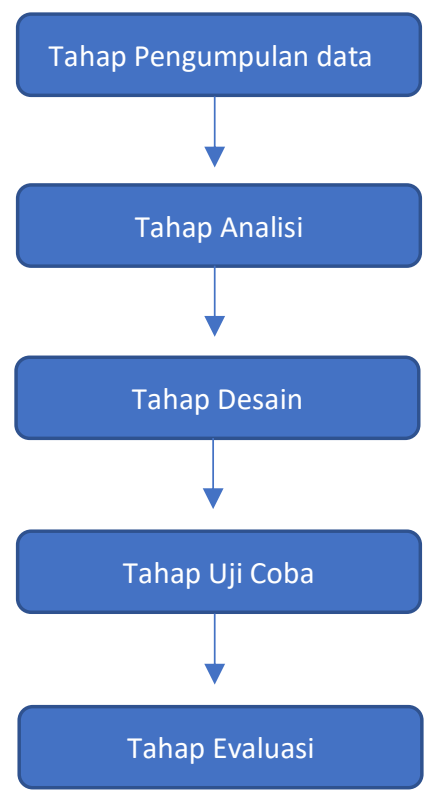

Gambar 7. Tahapan Penelitian

\section{Hasil dan Pembahasan}

Berikut ini adalah hasil aplikasi titip online produk UMKM berbasis android untuk memudahkan transaksi antara konsumen dan pelaku UMKM Adapun hasil dari uji coba aplikasi titip online produkUMKM berbasis android adalah sebagai berikut :

\section{- Halaman SplashScreen}

Tampilan SplashScreen ini adalah tampilan awal saat pertama kali aplikasi dibuka setelah dilakukan penginstalan tampilan ini akan muncul hanya sekali saja. 


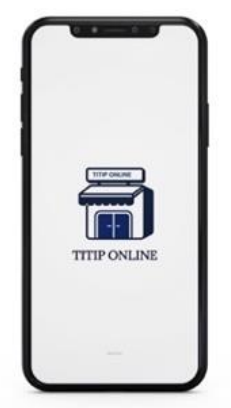

Gambar 8. Gambar Splash Screen

\section{- Halaman Login}

Halaman ini merupakan halaman untuk melakukan proses login menggunakan email yang tersimpan dalam sistem.

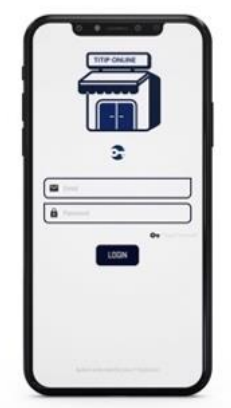

\section{Gambar 9. Gambar Halaman Login}

- Registrasi Pengguna

Halaman ini merupakan halaman untuk melakukan registrasi melengkapi data pengguna untuk dapat masuk ke dalam aplikasi.

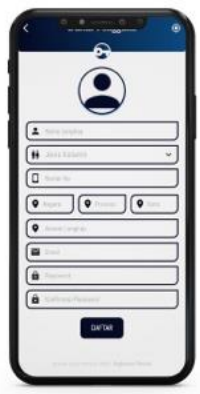

Gambar 10. Gambar Halaman Pengguna

- Registrasi Pemilik Toko

Halaman ini merupakan halaman untuk melakukan registrasi melengkapi data pemilik toko untuk dapat masuk ke dalam aplikasi.

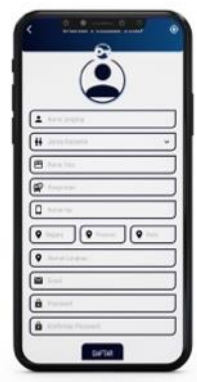

Gambar 11. Registrasi Pemilik Toko

- Halaman Utama Pengguna

Halaman ini merupakan halaman untuk melakukan pemilihan produk yang akan dipesan oleh pengguna dan dapat juga melihat detail pesanan pada menu pesanan yang tersedia di halaman utama pengguna kemudian terdapat menu edit profile yang dapat di gunakan untuk mengubah identitas yang tidak sesuai pada saat registrasi diawal.

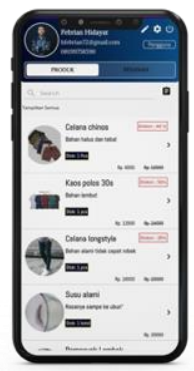

Gambar 12. Halaman Utama Pengguna - Halaman Utama Pemilik Toko

Halaman ini merupakan halaman untuk 
mengontrol produk yang sudah dinputkan terdapat fitur untuk melihat detail produk yang dipesan oleh pengguna.

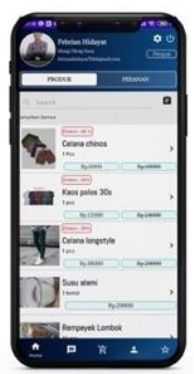

Gambar 13. Halaman Utama Pemilik Toko

- Halaman detail toko

Halaman ini merupakan halaman untuk melihat detail dari toko yang memilik produk yang telah kita pilih sebelumnya.

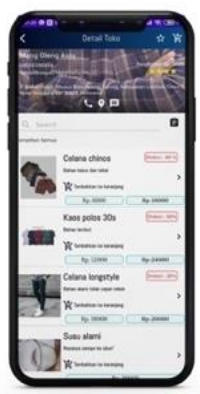

Gambar 14. Halaman detail toko

\section{- Halaman tambah produk}

Halaman ini merupakan halaman untuk menambahkan produk untuk pemilik toko.

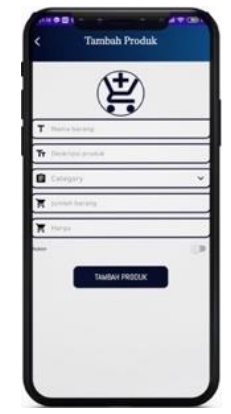

Gambar 15. Halaman tambah produk

- Halaman pemesanan

Halaman ini merupakan halaman untuk menentukan berapa produk yang akan kita beli dan mengetahui harga secara otomatis.

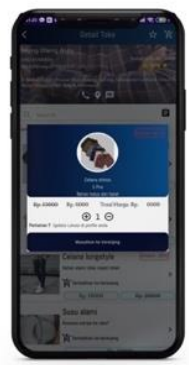

Gambar 16. Halaman pemesanan

\section{Kesimpulan}

Berdasarkan implementasi dan pembahasan yang telah dilakukan penulis maka terdapat beberapa kesimpulan yang dapat diambil diantaranya adalah sebagai beikut :

- Dibutuhkan suatu sistem yang dapat menghubungkan antara pemilik toko UMKM dan konsumen untuk melakukan transaksi jual beli secara lebih mudah.

- Perlunya penambahan fitur-fitur baru yang sesuai dan lebih memudahkan transaksi antara pemilik toko dan konsumen.

- Perlunya melakukan sosialisasi tentang sistem aplikasi baik itu kepada pemilik toko dan konsumen agar pemanfaatan aplikasi dapat lebih optimal 


\section{Daftar Pustaka}

[1] A. Sonita and R. F. Fardianitama, "Aplikasi E-Order Menggunakan Firebase Dan Algoritme Knuth," J. Pseudocode, vol. 5, no. 2, pp. 38-45, 2018.

[2] A. Sudianto and M. Sadali, "Infotek : Jurnal Informatika dan Teknologi Penerapan Aplikasi Berbasis Android Untuk Ternak Ayam Petelur Sebagai Wadah Untuk Menghubungkan Pemilik Modal Dengan Calon Peternak Pendahuluan dapat dikonsumsi oleh manusia. Ayam petelur merupakan ayam betina d," vol. 4 , no. 1 , pp. 87-95, 2021.

[3] S. Y. Frediyatma, "Aplikasi Pemesanan Makanan Berbasis Cloud dengan Platform Android," Merpati, vol. 2, no. 1, pp. 118126, 2016, doi: 10.24843/JIM.

[4] A. Sudianto and J. Sugiantara, "Website as Foundation Information Media under the auspices of Nahdlatul Wathan," J. Phys. Conf. Ser., vol. 1539, no. 1, pp. 3-8, 2020, doi: 10.1088/17426596/1539/1/012024.

[5] M. Wasil, L. Muhammad Samsu, and Y. Kuspandi Putra, "Sistem Informasi Geografis Untuk Pemetaan Homestay di Lombok Timur Berbasis Android," Infotek J. Inform. dan Teknol., vol. 3, no. 1, pp. 15-19, 2020, doi: 10.29408/jit.v3i1.1834.

[6] S. M. Sudianto Aris, "Penerapan Sistem Informasi Geografis (GIS) dalam Pemetaan Kerajinan Kain Tenun dan Gerabah untuk Meningkatkan Potensi Kerajinan di Kabupaten Lombok Timur," Infotek J. Inform. dan Teknol. J. Inform. dan Teknol., vol. 1, no. 2, pp. 64-71, 2018.

[7] F. D. Anggraeni, I. Hardjanto, and A. Hayat, "Pengembangan Usaha Mikro, Kecil, Dan Menengah (UMKM) Melalui Fasilitasi Pihak Eksternal Dan Potensi Internal," J. Adm. Publik, vol. 1, no. 6, pp. 1286-1295, 2013.

[8] Firdan Ardiansyah, "Firdan Ardiansyah | Pengenalan Dasar Android Programming.
Biraynara Copyright 2011," 2011.

[9] S. M. Sudianto Aris, "Penerapan Media Pembelajaran Interaktif Pelajaran Bahasa Indonesia Berbasis Android Untuk Kelas Vii Madrasah Tsanawiyah Nahdlatul Wathan Ketangga Sebagai Upaya Untuk Peningkatkan Minat Belajar Siswa," Infotek J. Inform. dan Teknol., vol. 2, no. 2, pp. 53-60, 2019.

[10] M. Ilhami, "Pengenalan Google Firebase Untuk Hybrid Mobile Apps Berbasis Cordova," J. IT CIDA, vol. 3, no. 124, pp. 16-29, 2017.

[11] A. Sudianto and M. Wasil, "Penerapan Sistem Informasi Geografis dalam Pemetaan Sebaran Kasus Gizi Buruk Lombok Timur merupakan salah satu Kabupaten yang berada di Provinsi Nusa Tenggara Barat yang terletak di sebelah Timur Pulau Lombok, Kabupaten Lombok Timur Gizi Buruk Malnutrisi," vol. 4, no. 2, pp. 142-150, 2021.

[12] A. F. Sallaby, F. H. Utami, and Y. Arliando, "Aplikasi Widget Berbasis Java," J. Media Infotama, vol. 11, no. 2, pp. 171-180, 2015.

[13] N. Wijaya, "Pelatihan Membuat Desain Logo Vector Menggunakan Adobe Illustrator dan Adobe Flash di SMK Bina Cipta Palembang," J. Pengabdi. Pada Masy., vol. 1, no. 1, pp. 25-29, 2016, doi: 10.30653/002.201611.5.

[14] J. Sathyan, A. Narayanan, N. Narayan, and K. V Shibu, "Mobile Programming," A Compr. Guid. to Enterp. Mobil., no. 50, pp. 301-354, 2012, doi: 10.1201/b12692-20.

[15] Sudianto Aris, "Penerapan Website Sebagai Sarana Promosi Wisata Budaya pada Kabupaten Lombok Timur," Infotek J. Inform. dan Teknol., vol. 1Sudianto, no. 1, pp. 11-17, 2018. 